\title{
Ringing in the New Year with an Investment Bust?
}

\author{
Kevin L. Kliesen
}

$\mathbf{R}$ eal outlays by firms for nonresidential capital equipment and software (E\&S) plunged 9 percent in 2001, a recession year; it was the largest decline since 1958 and the third largest since World War II. In an attempt to kickstart business investment, President Bush signed legislation in March 2002 that, among other things, allowed firms to immediately expense (depreciate) 30 percent of the cost of E\&S purchased between September 10, 2001, and September 11, 2004, and put into service before January 2005. In subsequent tax legislation signed in May 2003, this partial expensing provision was raised to 50 percent and the purchase date was moved back to December 31, 2004.

An increase in the depreciation allowance for capital goods increases the present value of the firm's deductions for tax purposes, which, all else equal, lowers the cost of capital. Accordingly, when the partial expensing provision reverts to its original level on January 1,2005, the present value of the depreciation deduction will be less-and the cost of capital will be higher-than what it was on December 31, 2004.

Although other factors were also probably at work, the recent growth of investment expenditures suggests that firms responded to this incentive, albeit with a lag. From 2001:Q4 to 2003:Q1, real E\&S investment fell at about a 1 percent annual rate; however, in the second quarter of 2003, real E\&S investment surged at an 11 percent annual rate and has since increased at a 14.5 percent annual rate through the third quarter of 2004.

With the expiration of the partial expensing provision fast approaching, some forecasters believe that many firms still plan to shift a portion of their planned capital expenditures from 2005 into 2004. If these expenditures are significant, then we would expect to see an upsurge in business investment in the final quarter of 2004 and then a drop-off in the first quarter of 2005 (or later).

Recent surveys compiled by the National Association of Business Economics and the Federal Reserve Bank of Philadelphia suggest that some firms have already shifted, or plan to shift, some of their capital outlays from 2005 into 2004. ${ }^{1}$ In August, forecasters expected a much larger slowdown in the growth of business fixed investment (BFI), from about 11 percent in 2004:Q4 to 6.5 percent in 2005:Q1. ${ }^{2}$ Since then, as seen in the table, forecasters have concluded that there will be both a smaller burst in investment spending in the fourth quarter and less of a lull in the first quarter.

Even though forecasters repeatedly changed their assessment of the relative strength of investment spending in 2004:Q4 and 2005:Q1-as viewed by the difference between the projected growth rates of real BFI in 2004:Q4 and 2005:Q1-they do not foresee such a swing in real GDP growth. This pattern is consistent with the fact that business investment (about 10 percent of GDP) tends to be more volatile than total spending. Thus, while forecasters expect some slowing in BFI growth in early 2005, they do not expect an investment bust (or, hence, a markedly slower growth of real GDP) to ring in the New Year.

\footnotetext{
${ }^{1}$ www.nabe.com/publib/indsum.htm; www.phil.frb.org/files/bos/bos0904.html.

${ }^{2}$ Business fixed investment includes structures, in addition to equipment and software.
}

\section{Are Forecasters Projecting a First-Quarter Slowdown? Percent changes at annualized rates}

\begin{tabular}{lcccccc} 
& \multicolumn{3}{c}{ Real GDP growth } & \multicolumn{3}{c}{ Real BFI } \\
\cline { 2 - 6 } Forecast date & $\mathbf{2 0 0 4 : Q 3}$ & $\mathbf{2 0 0 4 : Q 4}$ & $\mathbf{2 0 0 5 : Q 1}$ & $\mathbf{2 0 0 4 : Q 3}$ & $\mathbf{2 0 0 4 : Q 4}$ & $\mathbf{2 0 0 5 : Q 1}$ \\
\hline February 2004 & 3.9 & 4.1 & 3.6 & 10.4 & 11.0 & 8.8 \\
May 2004 & 4.1 & 4.0 & 3.8 & 11.5 & 10.3 & 7.7 \\
August 2004 & 3.5 & 4.0 & 3.8 & 9.9 & 10.9 & 6.5 \\
November 2004 & $\mathbf{3 . 9 ( A )}$ & 3.7 & 3.4 & $\mathbf{1 2 . 9 ( A )}$ & 10.0 & 8.5
\end{tabular}

SOURCE: Survey of Professional Forecasters published by the Federal Reserve Bank of Philadelphia. (A): Actual. 